CRÍTlCA, Revista Hispanoamericana de Filosofia

Vol. XXIV, No. 70 (abril 1992): 133-145

\title{
NOTAS BIBLIOGRAFICAS
}

Luis Martínez de Vclasco, Imperativo moral como interés de la razón, Editorial Orígenes, Madrid, 1987, 206 pp.

Desequilibrando la antinomia: el interés práctico del materialismo. (Un experimento kantiano)

Este libro es la segunda parte de la tesis doctoral del autor, cuya primera parte fue publicada por la misma Editorial Orígenes en el año de 1986 (Idealismo crítico e inmanencia en el pensamiento kantiano). En esta nueva obra se continúa la tentativa de lo que el autor llama, en la nota preliminar, "una interpretación matcrialista de la filosofía de Kant". Se puede recordar que en aquella obra Martínez de Velasco había escrito: "el idealismo crítico exigc la toma de postura favorable a las tesis denominadas por Kant 'empiristas'. No hace falta explicar que no se trata del empirismo metodológico, sino trascendental: resulta más conforme a la intención profunda de Kant denominarlo materialismo". Resulta francamente saludable que este libro renueve el objetivo del primero: constituirse en una lectura audaz, fuertemente "apropiativa" del pensamiento de Kant, en una especie de "revolueión copernicana" de la lectura: en vez de girar en torno a Kant, hacer que Kant gire en torno a nosotros. En este sentido, hay una ambigüedad no resuelta en el libro de Martíncz de Velasco, que se podrá juzgar positiva o negativamente: o bien el libro es considerado, como su autor lo deelara, "una interpretación materialista de Kant", o bien - como yo tengo tendencia a pensar-como una aplicación, rigurosa, de los esquemas de pensamiento kantianos para formular detalladamente una postura filosófica materialista propia. Es difícil aceptar el libro en cl primer sentido, pero cl mismo se vuelve excelente en la segunda manera de interprctarlo. La fuga de la letra en dirección al "espíritu" de los textos está claramente expuesta en varios pasajes de la obra: "la clave no consiste en saber qué hizo de hecho el filósofo de Königsberg, sino en represcntar qué tendría que haber hecho para que su sistema no se viese envuclto en titubeos y contradicciones"(p. 78), o, más fuertementc aún: "trataremos no 
tanto sobre lo que el propio Kant afirma en este sentido cuanto sobre lo que su propio método exige afirmar; no tanto sobre lo que dice cuanto sobre lo que debió haber dicho" (p. 143). Creo que el libro es interesante y fructífero si se considera claramente como un uso de Kant - perfectamente legítimo- y no como presunta tentativa de "coherentizar" el pensamiento de Kant tal como está expuesto en la letra.

Antes de comentar algunos de los aspectos más relevantes de la tentativa de Martínez de Velasco, voy a ofrecer una rápida descripción del libro: contiene una introducción mínima, en donde sólo se anuncia el itinerario de la obra (pp. 27-29). El libro consta de cuatro capítulos, los dos primeros dedicados a cuestiones éticas stricto sensu, y los dos últimos a problemáticas ético-políticas. En el capítulo I (pp. 31-50), se trata de la noción de "trascendental" y de algunos problemas iniciales de la ética kantiana (incluyendo una interesante sección sobre "el carácter abstracto de la ética kantiana"). El capítulo II (pp. 51-129) trata de lo que el autor interpreta como críticas kantianas contra el idealismo antropomórfico, que se subdivide en la crítica al fatalismo ético (p. 64), al estcticismo moral (p. 68) y al eudemonismo (utilitarismo moral, p. 71). En la parte positiva del capítulo el autor expone, siempre al hilo de sus intereses, los valores ilustrados fundamentales, como los de la dignidad, la humanidad y, principalmente, el deber, como "clave de bóveda de la ética kantiana". En el capítulo III (pp. 131-148) el autor trata de las controvertidas relaciones entre ética y política, y de la cuestión de la propia moralización de la política a la luz del pensamiento kantiano, contra el escepticismo liberal que separa nítidamente ambas cosas, soterrando la ética en el idealismo y la política en un realismo crudo y utilitario. En el último capítulo, se trata del pensamiento kantiano en su contacto con los problemas de la sociedad alemana de su época, dando énfasis a la cuestión de la propiedad privada y, en general, de la desigualdad humana, política y económica, estudiándose finalmente los contactos de la filosofía kantiana con la historia. La obra está precedida por un prólogo de José María Laso Prieto en donde se encontrarán buenas observaciones acerca de la hermenéutica crítica del autor.

Imperativo moral..., a pesar de las apariencias, no es precisamente lo que la Academia llamaría "un libro sobre Kant" (iuno más!) sino, fundamentalmente, una crítica de las bases filosóficas del liberalismo social, que utiliza las ideas "ilustradas" —representa- 
das por Kant- para combatirlas. Del liberalismo son criticados, fundamentalmente, su "idealismo" fuertemente antropomorfizante, y su esencial fragmentación individualista, con su consecuente negación de toda pretensión de universalidad (Martínez de Velasco habla de un interés del liberalismo por la relatividad de la moral). Nociones como "libertad", "yo" y "felicidad" son identificadas por el autor como nociones esencialmente adscriptas al modelo liberal. Del pensamiento ilustrado, le interesa acentuar fundamentalmente: a) su pretensión de universalidad vinculante; b) su materialismo desantropomorfizante, y c) su utopismo, en el sentido de un sistemático rehusarse a realizar el ideal ético en la sociedad de facto vigente. En última instancia, Kant será criticado, en los dos últimos capítulos, en el plano político, por no haber aplicado coherentemente su propio método crítico - tal como lo desarrolló en la reflexión moraly haber conservado, con eso, la estructura filosófica del liberalismo. A la luz del pensamiento kantiano, la pregunta primordial deberá ser entonces: "Cómo es posible una ética universal en una sociedad fragmentada" (p. 73).

Como el título del libro ya lo indica, la famosa noción de "interés" ocupa un destacado lugar dentro de la argumentación. Entre el idealismo —que estaría en las bases de la visión liberal de la sociedad- y el materialismo —que se vincularía con los ideales ilustrados - no puede haber ninguna decisión "científica" basada en verificaciones, sino tan sólo un "interés" racional, en el sentido kantiano (no, ciertamente, una decisión abitraria). El autor del libro, en ese sentido, trata de convencer al lector de que hay más interés en la alternativa materialista, en la medida en que la idealista está irremediablemente comprometida, precisamente, con lo arbitrario, lo antropomórfico, lo religioso y con todo lo que inhibe el desarrollo de la humanidad del hombre. "La heteronomía de la ética liberal (o sea, su franca irracionalidad) viene a perpetuarse en cada uno de los momentos conceptuales en que se vertebra sin que en su despliegue llegue a quedar anulada la arbitrariedad de su origen" (p. 93). Esa vinculación con lo racional evita que la alternativa materialista sea "dogmática" (pp. 98-99).

En los dos últimos capítulos, el autor intenta mostrar que Kant se ha mantenido dentro de la arbitrariedad irracional dcl idealismo, base del liberalismo egoísta, eudemonista, etc., en su filosofía política y, en parte, en su filosofía de la historia, sin utilizar los propios recursos emancipadores contenidjos en su reflexión ética. A pesar de 
ser fuertemente expositiva, la argumentación sirve para completar la idea que el autor tiene de las relaciones entre moral y política desde su planteamiento "materialista-ilustrado". El punto culminante de este experimento está en las páginas 160 y siguientes, cuando se analizan las relaciones entre el pensamiento kantiano y la cuestión de la propiedad privada. Según Kant, “los principios teóricos de la propiedad privada se disipan en la esfera de lo inteligible", y Martínez de Velasco comenta: "No es posible dejar de ver aquí una claudicación absoluta ante el hecho de la propiedad privada, que [...] merece, ciertamente, un análisis verdaderamente reflexivo cuyas condiciones de posibilidad (el imperativo moral) ya están dadas de antemano" (p. 161). El cuerpo reflexivo liberal expulsa del plano político la injusticia y el desequilibrio, pero al precio de que ellos vuelvan inevitablemente a filtrarse en el plano económico (p. 154), y Kant "reproduce conscientemente el modelo conceptual liberal en lo que éste tiene de ficticiamente unitario dentro de la fragmentación entre política y economía" (p. 169).

Para terminar, quiero hacer dos observaciones críticas.

En primer lugar, continúo creyendo - tal vez definitivamente preso en la estructura de conciencia liberal- que la elección entre idealismo y materialismo (y, en general, cualquier desequilibrio de la antinomia para un lado o para cl otro) no puede ser nunca otra cosa que una decisión, guiada ciertamente por la racionalidad aun cuando perturbada sistemáticamente por el inconsciente y las ideologías. Pcro me rehúso a darle a la propia racionalidad, el contenido de uno de los dos lados de la antinomia, de tal manera que si uno elige uno de los dos lados, la otra opción quede irremediablemente sumergida en la "irracionalidad". En su crítica contra la aproximación - casi identificatoria - que hace Kant entre la racionalidad y la moralidad, E. Tugendhat ha señalado que hasta un criminal puede actuar racionalmente, no digamos ya un filósofo idealista, cuyos crímenes parecen ser menores. Después de todo, tanto la tesis como la antítesis dan origen a sendas teorías morales: si toda la racionalidad-moralidad-dignidad, etc., etc., están —vía “intereses de la razón" - tan sólo de un lado, ¿̇habremos de decir entonces, por ejemplo, que las éticas empiristas humanas están en favor de la indignidad humana y la irracionalidad? Parece francamente dogmático decir tanto, aun cuando se tengan razones poderosas para no ser un humeano. Sin embargo, deberíamos comprometernos con ese dogmatismo, como consecuencia directa de haber pretendido darle a la vo- 
luntad humana un contenido determinado (idealista o materialista). No toda noción de "libertad" me parece una noción liberal. Creo que la opción es: o bien aceptamos una cierta idea de libertad formal, con sus peligros - muy bien indicados por el autor- de resbalar hacia el decisionismo, o bien le damos a la voluntad humana un contenido claramente dogmático, por ejemplo, materialista. $\mathrm{El}$ autor prefiere arrostrar los peligros de esta segunda alternativa.

En segundo lugar, en el libro de Martínez de Velasco se elogia - y creo que con frankfurtiana razón- el carácter utópico del pensamiento ilustrado, en el sentido de rehusarse a materializar el ideal ético en el estado presente de la sociedad. En este sentido, el autor resalta la existencia de una "dimensión cívica", carente de "partidismo", impidiendo así "el acercamiento de la reflexión kantiana hacia la política empírica (burguesa) realizada en su tiempo" (p. 131). Kant es, así, elogiado por "haberse situado desde el inicio en el ámbito utópico del noúmeno" (p. 158). (Véanse también las últimas páginas del libro.) Ahora bien, el autor elogia sin rctaceos este carácter utópico y nouménico del pensamiento crítico que se niega a coincidir con lo real cuando lo real es la burguesía, pero ¿continuaría elogiándolo cuando lo real fuese, digamos, la sociedad sin clases o la abolición de la propiedad privada? $\mathrm{O}$, en ese caso, ¿el pensamiento crítico debería cambiar súbitamente de naturaleza y transformarse en pura coincidencia con lo real? ¿Hasta qué punto el pensamiento crítico funcionaría tan sólo como un arma? Si alguna característica de lo real llevase a la abolición del componente utópico del criticismo, ¿no correríamos entonces el riesgo de resucitar alguna de esas estructuras religiosas "conciliadoras" que son tan bien criticadas por el autor a lo largo de todo el libro?

Independientemente de éstas y otras críticas posibles, el libro de Martínez de Velasco representa un interesantísimo experimento filosófico, en el que uno puede ver - entre tantos libros eternamente "programáticos"- el modo kantiano de filosofar in action. El mejor elogio que se puede hacer del libro es que el placer y provecho de su lectura no son empañados aun si finalmente fracasa el experimento. Martínez de Velasco ha hecho saltar por los aires cuestiones categoriales de carácter fundamental, y la reflexión a la que esa propuesta nos obliga no dejará de tener el valor indestructible de un camino del pensamiento, sin salida y sin rctorno, como todos ellos.

JULIO CABRERA 